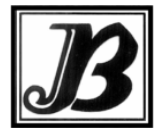

J. bio-sci. 20: 41-48, 2012

ISSN 1023-8654

http://www.banglajol.info/index.php/JBS/index

\title{
SCREENING OF MULTIDRUG-RESISTANT BACTERIA OF ANTIBIOTIC-ASSOCIATED DIARRHEA AND THEIR INHIBITION BY LEAF EXTRACTS OF MORINGA OLEIFERA LAMK
}

\author{
M M Akhtar, M S Islam, M F Begum*, M Anisuzzaman, M F Alam \\ Department of Botany, University of Rajshahi, Rajshahi-6205, Bangladesh
}

\begin{abstract}
Context: Emergence of multi drug resistance bacteria (MDRB) to human pathogenic infection is increasing day by day but the number of new drugs to overwhelm the problem is not sufficient. Evidences revealed that Moringa oleifera Lamk. has various pharmaceutical activities like antibacterial, antifungal, antispasmodic, anti-inflammatory, anticancer and diuretic. Herbal treatment may be one of the possible ways to treat diseases caused by multidrug-resistant bacteria.

Objectives: The present research was undertaken to screen of multidrug resistant bacteria (MDRB) from antibiotic-associated diarrheal samples and to evaluate the potentiality of $M$. oleifera leaf extracts on these bacteria with the view to provide scientific evidence for its application in health remedy.

Materials \& Methods: Antibiotic-associated diarrheal fecal specimens were collected from pediatric ward of Rajshahi Medical College and cultured onto MacConkey agar. MDRB were determined by antibiotic susceptibility test, using disc-agar diffusion method. Biochemical tests of the MDRB were done according to Bergey's Manual of Determinative Bacteriology for identification of the species. Dried and fresh leaf of $M$. oleifera was used to prepare exaction with or without solvents such as hot water, cold water, chloroform, petroleum ether, acetone and ethanol, separately. Antibacterial assay was done by disc diffusion method and minimum inhibitory concentration of the extracts was also measured.

Results: In the present study seven isolates were screened as MDRB and the highest prevalence $(42.86 \%)$ was occurred in the age group of $25-36$ months and the lowest (14.28) was in the group of $<1$ and 1-6 months. Ethanol extract of dried leaf of M. oleifera Lamk. showed moderate inhibitory activity against all of the isolates while petroleum ether, chloroform and acetone extracts of dried leaf have no inhibitory effect. Fresh leaf sap powder in DMSO exhibited strong inhibitory effect against all of the test bacteria where as hot aqueous extract could not show any inhibition. The minimum inhibitory concentrations (MIC) of the potent extracts ranged 937.5 to $3750 \mu \mathrm{g} / \mathrm{ml}$ and 7.9 to $234.4 \mu \mathrm{g} / \mathrm{ml}$ in dried and fresh leaf extracts, respectively.

Conclusion: The present data indicates that $M$. oleifera leaf extract possess antimicrobial potential to control of MDRB causes infection thus it can be used as a novel drugs in future.
\end{abstract}

Key words: Antibiotic-associated diarrhea (AAD), Antibiotic susceptibility, Multidrug-resistant bacteria, Moringa oleifera Lamk., Minimum inhibitory concentrations (MIC).

\section{Introduction}

Antibiotic-associated diarrhea (AAD) occurs in about $5-30 \%$ of patients either early antibiotic therapy or up to two months after the end of the treatment (Bartlett et al. 1978, McFarland 1998, Wiström et al. 2001). World Health Organization (WHO) defines antibiotic-associated diarrhea as 3 or more abnormally loose bowel movements in a 24-hr period (Tankanow et al. 1990, D'Souza et al. 2002). The disruption of the normal enteric flora caused by antibiotics may lead to overgrowth of pathogens and functional disturbances of the intestinal carbohydrate and bile acid metabolism, resulting in osmotic diarrhea (Hogenauer et al. 1998). The

* Corresponding author E-mail: ferdrita@yahoo.com 
severity of antibiotic-associated diarrhea may range from a brief, self-limiting disease to devastating diarrhea with electrolyte disturbances, dehydration, crampy abdominal pain, pseudomembranous colitis, toxic megacolon, or even death (Bartlett 1992).

Repeated and improper uses of antibiotics are primary causes of the increase in drug-resistant bacteria. The most common culprit broad-spectrum antibiotics which include ampicillin, clindamycin, cephalosporin, sometimes erythromycins (Erythrocin), fluoroquinolones (Ciprofloxin) and tetracycline also can cause antibiotic-associated diarrhea (Antibiotic-associated diarrhea 2009). Bacteria gain antibiotic resistance genes through plasmid, transposones and integrons which result in mutations in genes responsible for antibiotic uptake. If a bacterium carries several resistance genes, it is termed as multi-resistant or super bug (Antibiotic resistance 2008) that is more dangerous and problematic to people. In the present scenario of emergence of multidrug resistance to human pathogenic infections including $A A D$, it has become very necessary to search for new antimicrobial substances from other sources such as plants. Herbal treatment is one possible way to treat diseases caused by multidrug-resistant bacteria (Olukoya et al. 1993).

The present research reports the first attempt to study the antimicrobial activity of Moringa oleifera Lamk. against multidrug resistant bacteria (MDRB) of AAD. Several evidences revealed that $M$. oleifera has various pharmaceutical activities such as antibacterial (Eilert et al. 1981, Dayrit et al. 1990), antifungal, antispasmodic, anti- inflammatory, anticancer and diuretic activities (Caceres et al. 1992). Its leaves contain 2-nitrile glycosides, niazirin and niazirinin, and 3-mustard oil glycosides, isothiocyanate, niaziminin A and B, which are reported to be responsible for hypotensive activity (Guevara et al. 1999) Therefore, the present attempt has been under taken to screen of MDRB from fecal specimens of AAD-patients and evaluate the potentiality of $M$. oleifera leaf extracts on these bacteria with the view to provide scientific evidence for its application in health remedy.

\section{Materials and Methods}

Subjects and Isolation of AAD-bacteria: A total 50 antibiotic-associated diarrheal fecal specimens were collected in sterile screw-capped tube from pediatric ward of Rajshahi Medical College Hospital, Rajshahi, Bangladesh, during March to April, 2007. Those specimens were obtained from diarrhea affected children (136 months) during the first two weeks after the starting of the antibiotic treatment, because this period most likely reflects the effect of antibiotic use. The fecal specimens were then cultured following Holt et al. (1994) by plated onto MacConkey agar $(0.001 \mathrm{mg} / \mathrm{ml})$ at $37^{\circ} \mathrm{C}$ for about $24 \mathrm{~h}$. After the growth of bacteria, the pink color colonies were screened as lactose fermenter.

Antibiotic susceptibility and biochemical tests: MDRB were determined by antibiotic susceptibility test, using the disc-agar diffusion method, as recommended by the Clinical and Laboratory Standards Institute (CLSI 2004). Commercial antimicrobial discs (Oxoid), used in this experiment were ampicillin $(10 \mu \mathrm{g})$, amoxicillin $(30 \mu \mathrm{g})$, cephalosporin $(30 \mu \mathrm{g})$, erythromycin $(30 \mu \mathrm{g})$, ciprofloxacin $(5 \mu \mathrm{g})$ and tetracycline $(30 \mu \mathrm{g})$. Hundred $\mu \mathrm{l}$ of $18 \mathrm{~h}$ old culture of standardized inoculums of each tested bacteria was spread onto nutrient agar (Difco Laboratories) plate and left for $30 \mathrm{~min}$. Commercial antibiotic discs with standard concentration were carefully placed on the test organism-seeded plates and incubated at $37^{\circ} \mathrm{C}$ temperature for $16 \mathrm{~h}$. Antibiotic susceptibility was evaluated by the diameter of inhibition zone $(\mathrm{mm})$ compared with the standard manual. Biochemical tests of the MDRB were done according to Bergey's Manual of Determinative Bacteriology (Holt et al. 1994) using their respective standard strain for confirmation of the species. Gram staining, indole, Kligler's iron agar (KIA), methyl red (MR), Voges-Proskauer (VP), urease, citrate utilization and catalase tests were done. 
Preparation of plant extracts: Fresh mature leaves of $M$. oleifera were collected from Rajshahi University Campus, Rajshahi, Bangladesh, during June, 2007 and authenticated by the plant taxonomist at the Department of Botany, University of Rajshahi, Bangladesh. The leaves were cleaned and dried in shade at room temperature $\left(32-35^{\circ} \mathrm{C}\right.$ ) for five days (Doughari 2006) and reduced to powder with a grinder. Dried plant powder $(30 \mathrm{~g})$ was mixed with $300 \mathrm{ml}$ of petroleum ether, chloroform, ethanol and acetone separately in a conical flask and kept on an orbital shaker for $24 \mathrm{~h}$. The crude extracts were filtered, concentrated in a rotary evaporator and allowed to dry at room temperature and used in the experiment. Fresh leaves $(20 \mathrm{~g})$ was crushed directly without adding any solvent and leaf sap obtained was filtered and used for antibacterial activity test. Fresh leaves $(100 \mathrm{~g})$ was crushed directly without adding any solvent and dried at room temperature and $1.3 \mathrm{~g}$ dried material was then powdered and dissolved in $10 \mathrm{ml}$ of dimethyl sulfoxide (DMSO). Again $20 \mathrm{~g}$ fresh leaves was crushed adding $50 \mathrm{ml}$ of cold water, hot water, chloroform, petroleum ether, acetone and ethanol, separately. Then the leaf sap was filtered and applied for antibacterial activity test.

Antibacterial assay and minimum inhibitory concentration (MIC): Antibacterial potentiality of crude extracts of M. oleifera leaves was evaluated by the paper disc diffusion method (Aida et al. 2001). Sterile filter paper discs $(6 \mathrm{~mm})$, previously impregnated with $10 \mu \mathrm{l}$ of various known concentrations of extracts were carefully placed on the test organism-seeded plates and incubated at $37^{\circ} \mathrm{C}$ temperature for about $16 \mathrm{~h}$. For each extract three replicate trials were conducted against the test organism to confirm the reproducible results. Sterile blank paper discs were impregnated with same amount of solvent separately and used as negative control and tetracycline $(100 \mu \mathrm{g} / \mathrm{ml})$ contained paper disc was used as positive control.

Serial dilutions of the crude extracts were made with different ranges for dried leaf extract $(30-0.05 \mathrm{mg} / \mathrm{ml})$, fresh leaf sap (29.375 $-0.014 \mathrm{mg} / \mathrm{ml})$, fresh leaf sap powder dissolved in DMSO $(32.5-0.004 \mathrm{mg} / \mathrm{ml})$, fresh leaf solvent extracts $(30-0.004 \mathrm{mg} / \mathrm{ml})$ and tetracycline $(100-12.5 \mu \mathrm{g} / \mathrm{ml}) .0 .5 \mathrm{ml}$ of each concentration of the extract was added to $2 \mathrm{ml}$ of nutrient broth and then $100 \mu \mathrm{l}$ of standardized inoculum $\left(10^{6} \mathrm{cfu} / \mathrm{ml}\right)$ was introduced to each tube and incubated aerobically at $37^{\circ} \mathrm{C}$ for $24 \mathrm{~h}$. Uninoculated tubes containing growth medium and extract were used as controls. The lowest concentrations of the extracts that produced no visible bacterial growth (no turbidity) compared to control was regarded as MIC.

\section{Results}

\section{Enumeration and isolation of AAD-bacteria}

Total numbers of colonies of different AAD-bacteria were enumerated from each sample. The highest number of colony was recorded $66 \pm 0.7$ cfu/plate in the age group of 25-36 months. But the lowest number of colony was recorded $21.5 \pm 1.2$ cfu/plate in the age group of 7-12 months (Fig.1). Initially, 25 isolates were isolated out of 50 samples screened on MacConkey agar medium. These isolates were subjected to test of antibiotic susceptibility for the determination of multidrug-resistant bacteria.

Screening of multi drug-resistant bacteria

\section{Antibiotic susceptibility}

Only 7 out of 25 isolates were found resistant to multiple antibiotics. Among the isolates, S/11 isolate was resistant against only two antibiotics (EryR and Tet ${ }^{\mathrm{R}}$ ) and other 6 isolates were resistant to three or more antibiotics. Almost all of the isolates were sensitive to ciprofloxacin and cephalosporins without S/24 and S/7 isolates (table 1). The highest resistance was observed in tetracycline (100\%) followed by ampicillin (85.7\%), amoxicillin (57.1\%), erythromycin (71.4 \%) and ciprofloxacin (42.8\%) and the lowest was observed in cephalosporins (28.6 \%) as shown in Fig 2.

The highest rate of isolation of multidrug-resistant bacteria was found $42.86 \%$ in the age group of 25-36 months and the lowest rate was found $14.28 \%$ in the age group of $<1$ and 1-6 months (Fig 1). 
Table 1. Bacterial isolates and antibiotic resistance profiles

\begin{tabular}{ll}
\hline Isolate & Antibiotic resistance \\
\hline$S / 11$ & Ery, Tet \\
$S \quad S / 13$ & Amp, Amo, Ery, Tet \\
$S / 9$ & Amp, Ery, Tet, Cip \\
$S / 24$ & Amp, Amo, Cep, Tet, Cip \\
$S / 3$ & Amp, Amo, Ery, Tet \\
$S / 7$ & Amp, Amo, Cep, Tet, Cip \\
$S / 19$ & Amp, Ery, Tet \\
\hline
\end{tabular}

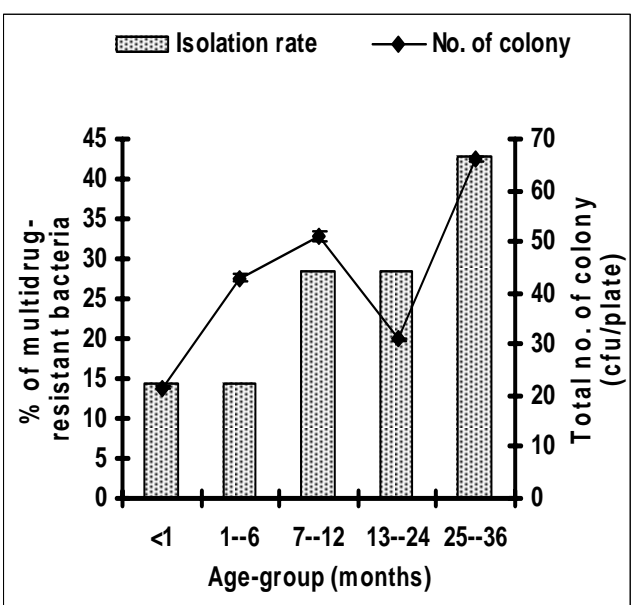

Fig 1. Total number of colony (cfu/plate) and isolation rate of multidrug-resistant bacteria in relation to age distribution of antibiotic-associated diarrheic pediatric patients

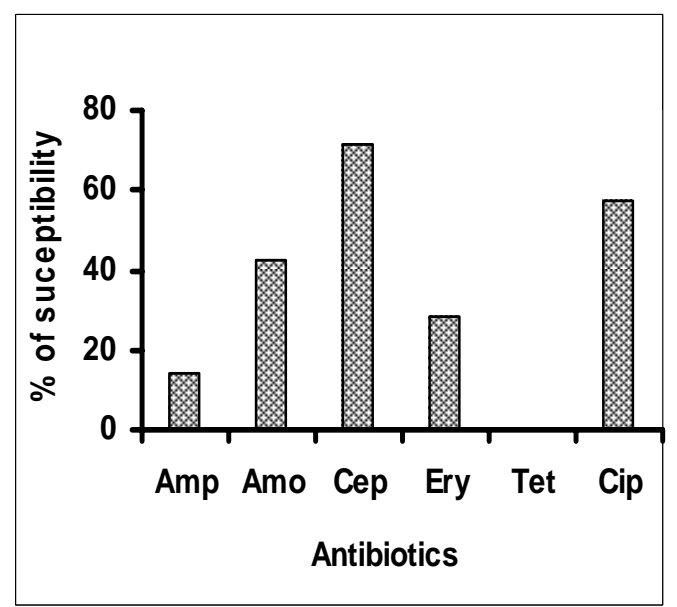

Fig 2. Antibiotic susceptibility of isolated bacteria. Amp = Ampicillin; $\quad$ Amo = Amoxicillin; Cep = Cephalosporins; Ery = Erythromycin; Tet $=$ Tetracycline; $\quad$ Cip $=$ Ciprofloxacin

\section{Identification of multi drug-resistant bacteria}

For identification of multidrug-resistant bacteria different biochemical tests were carried out and the results are summarized in Table 2. On the basis of growth on MacConkey agar, morphological and biochemical test, the selected multidrug-resistant bacteria were identified as Escherichia coli, Shigella sp., Salmonella sp., Citrobacter sp., Klebsiella sp., Enterobacter sp. and Proteus sp. In the patients with antibiotic-associated diarrhea Escherichia coli, Salmonella sp. and Klebsiella sp. observed by Hovius and Rietra (1982), Hogenauer et al. (1998) and Bartlett (2002). 


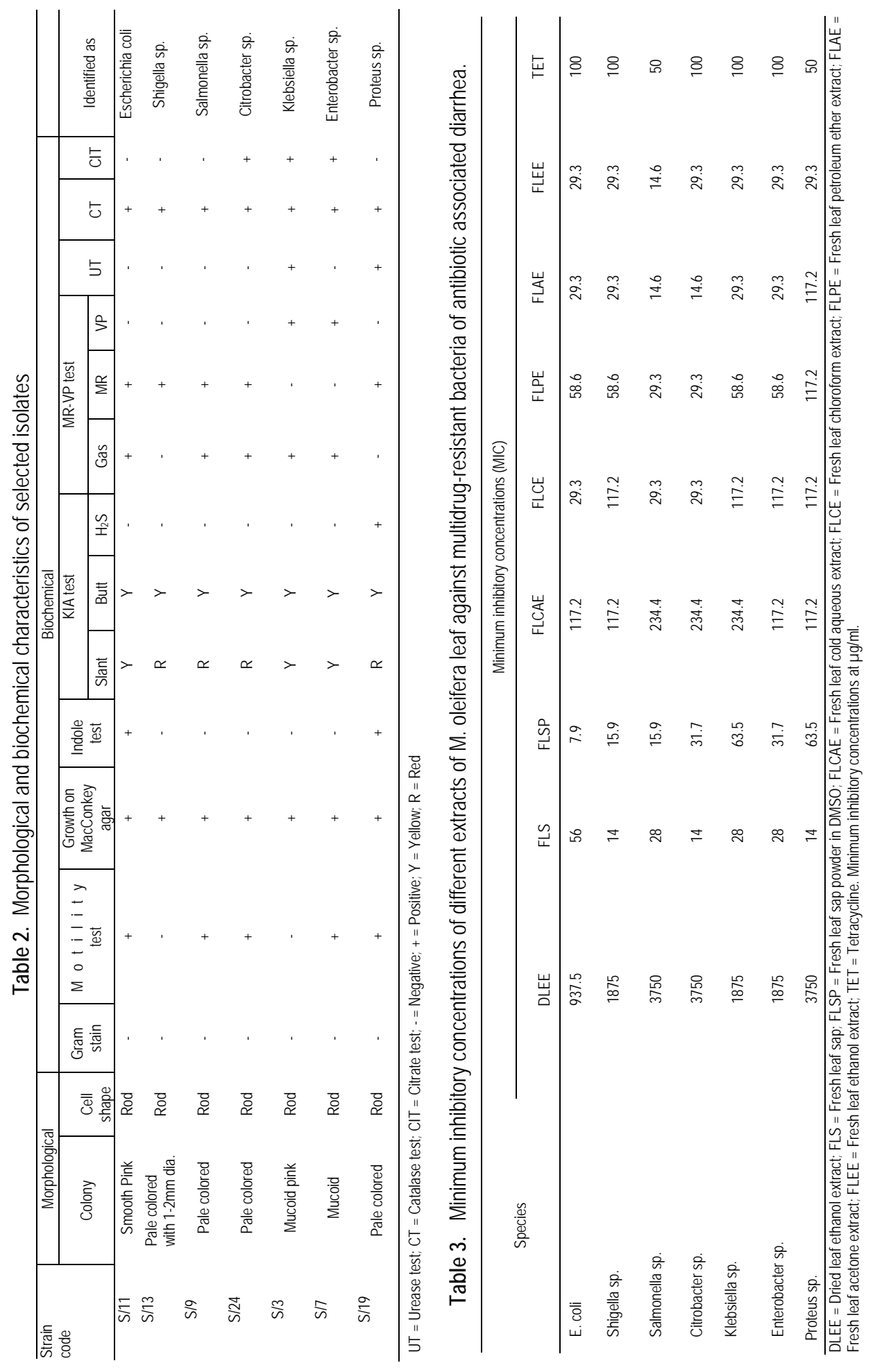




\section{Antibacterial assay}

Dried leaf extracts and fresh leaf extracts of $M$. oleifera were selected for antibacterial activity against seven different multidrug-resistant bacteria of AAD. All the extracts exhibited different degrees of antibacterial activity which were compared with the standard reference (control). Depending on the measured values of the complete inhibition diameter of the zone, the antibacterial activity can be classified as 6-9 mm: week antibacterial activity; 10-15 mm: slight antibacterial activity; $16-20 \mathrm{~mm}$ : moderate antibacterial activity and >20: strong antibacterial activity (Arora and Bhardwaj 1997).

In dried leaf, ethanol extract showed moderate effect against all of the isolates and the highest inhibition zone $(20.07 \pm 0.5 \mathrm{~mm}$ ) was found against $E$. coli (Fig. 3) at $30 \mathrm{mg} / \mathrm{ml}$ concentration while petroleum ether, acetone and chloroform extracts did not exhibit any inhibitory activity. In another study Jabeen et al. (2008) reported that crude extract of $M$. oleifera had strong activity against Fusarium solani, Bacillus subtillis, and Staphylococcus aureus. The relatively high potency of the ethanol extract may be attributed to the dissolving power of alcohols (Majorie 1999).

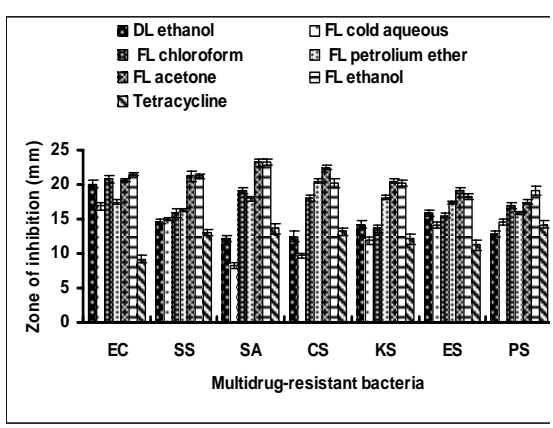

Fig 3. Inhibitory activity of solvent extracts of dried and fresh leaf of $M$. oleifera against multidrug resistant bacteria. 30 $\mathrm{mg} / \mathrm{ml}$ for extracts, $100 \mu \mathrm{g} / \mathrm{ml}$ for tetracycline.

$\mathrm{EC}=$ Escherichia coli; $\mathrm{SS}=$ Shigella sp.; $\mathrm{SA}=$ Salmonella sp.; $\mathrm{CS}=$ Citrobacter sp.; KS = Klebsiella sp.; ES = Enterobacter sp.; PS = Proteus sp.; DL = Dried leaf; FL = Fresh leaf.

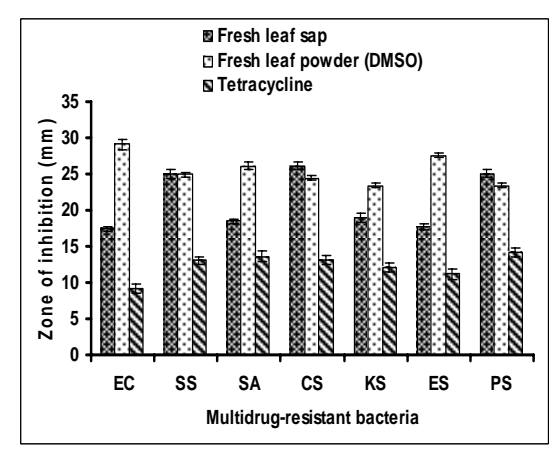

Fig 4. Inhibitory activity of fresh leaf sap of $M$. oleifera against multidrug resistant bacteria.

$29.375 \mathrm{mg} / \mathrm{ml}$ for fresh leaf sap without solvent, $32.5 \mathrm{mg} / \mathrm{ml}$ for fresh leaf sap powder in DMSO and $100 \mu \mathrm{g} / \mathrm{ml}$ for tetracycline.

Fresh leaf extracts revealed a potential antibacterial activity against all of the isolates. Fresh leaf sap powder extract dissolved in DMSO exhibited strong inhibitory effect against all of the test bacteria with their zones of inhibition ranges $23.4 \pm 0.3$ to $29.1 \pm 0.7 \mathrm{~mm}$ (Fig. 4) at $32.5 \mathrm{mg} / \mathrm{ml}$. Fresh leaf sap without adding any solvent also exhibited strong zone of inhibition against Shigella sp. $(25.07 \pm 0.6 \mathrm{~mm})$, Citrobacter sp. $(26.07 \pm 0.5 \mathrm{~mm})$ and Proteus sp. $(25.07 \pm 0.5 \mathrm{~mm})$ at $29.375 \mathrm{mg} / \mathrm{ml}$. Both acetone and ethanol extract of fresh leaf showed strong antibacterial effect against $E$. coli, Shigella sp., Salmonella sp., Citrobacter sp. and Klebsiella sp. On the other hand, cold aqueous, chloroform and petroleum ether extract displayed a moderate inhibitory effect against all of the test bacteria. Hot aqueous extract and solvents (negative control) could not show any inhibitory activity against test organism. Doughari et al. (2008) demonstrated that acetone extract of Senna obtusifolia leaf showed highest activity followed by dichloromethane extracts while water extract exhibited least activity against all the clinical isolates Neisseria gonorrheae, Salmonella sp., Pseudomonas aeruginosa, Proteus vulgaris, Staphylococcus aureus.. Different solvents have various degrees of solubility for different 
phyto-constituents (Majorie 1999). Results revealed that the fresh leaf sap powder extract dissolved in DMSO showed greater antibacterial activity compare to dried leaf solvents extract. This finding is interesting because in the traditional method of treating a bacterial infection, decoction of the plant parts is employed whereas in the present study organic solvent (DMSO) extract was shown to provide a better antibacterial activity. These observations may be attributed to the nature of biological active components whose activity can be enhanced in the presence of DMSO.

\section{MIC determination}

The MIC values obtained for the extracts against the isolates varied from one extract to the other (Table 3). The MIC of the fresh leaf extracts ranged $7.9-234.4 \mu \mathrm{g} / \mathrm{ml}$, with the fresh leaf sap powder (DMSO) extract demonstrating the lowest values (MIC $7.9 \mu \mathrm{g} / \mathrm{ml}$ ) against $E$. coli, followed by fresh leaf sap against Shigella sp. $(14 \mu \mathrm{g} / \mathrm{ml})$, Citrobacter sp. $(14 \mu \mathrm{g} / \mathrm{ml})$ and Proteus sp. $(14 \mu \mathrm{g} / \mathrm{ml})$. Ethanolic dried leaf extract demonstrated comparatively higher MIC ranged $937.5-3750 \mu \mathrm{g} / \mathrm{ml}$ and the lowest MIC $(937.5 \mu \mathrm{g} / \mathrm{ml}$ ) exhibited against $E$. coli. Most of the MIC values were lower indicating the extracts could be bactericidal in action. Lower MIC values and higher zones of inhibition for fresh leaf extracts is the indication of high efficacy which in accordance with the results obtained by Doughari et al. (2008). Antimicrobial properties of substances are desirable tools in the control of undesirable microorganisms in the treatment of infections (Aboaba et al. 2006).

\section{Conclusion}

The present results support the folkloric usage of the studied plant and suggest that the fresh leaf sap powder extract dissolved in DMSO posses certain constituents which can be used as antimicrobial agents to treat of infectious disease caused by multidrug-resistant bacteria. But in vivo studies on this medicinal plant are necessary and should seek to determine toxicity of the active constituents, their side effects, pharmacokinetic properties and diffusion in different body sites with the view to formulating novel chemotherapeutic dugs.

\section{Acknowledgement}

The authors would like to thank Professor Abu Bakar Siddique, Pediatric Department, Rajshahi Medical College Hospital, Rajshahi, Bangladesh, for his cordial help to collect the samples.

\section{References}

Aboaba OO, Smith SI, Olude FO. 2006. Antibacterial effect of edible plant extract on Escherichia coli 0157:H7. Pak J Nut 5(4), 325-32. http://dx.doi.org/10.3923/pin.2006.325.327

Aida P, Rosa V, Blamea F, Tomas A, Salvador C. 2001. Paraguyan plants used in traditional medicine. J Ethnopharm 16, 93- 98.

Antibiotic resistance. 2008. http://en.wikipedia.org/wiki/ Antibiotic_resistance. Accessed on: 8 Aug 2009.

Antibiotic-associated diarrhea (2009) MayoClinic.com. http://www.mayoclinic.com. /health/antibiotic-associateddiarrhea/DS00454/DSECTION=causes. Cited 23 June 2009

Arora DS, Bhardwaj SK. 1997. Antibacterial activity of some medicinal plants. Geo Bios 24, 127-131.

Bartlett JG. 1992. Antibiotic-associated diarrhea. Clin Infect Dis 15, 573-581. http://dx.doi.org/10.1093/clind/15.4.573

Bartlett JG. 2002. Antibiotic-associated diarrhea. NEJM 346(5), 334-339. http://dx.doi.org/10.1056/NEJMcp011603 
Bartlett JG, Chang TW, Gurwith M, Gorbach SL, Onderdonk AB. 1978. Antibiotic-associated pseudomembranous colitis due to toxin producing Clostridia. N Engl J Med 298, 531-534. http://dx.doi.org/10.1056/NEJM197803092981003

Caceres A, Sarawia A, Rizzo S, Zabala L, Lean DE, Nove F. 1992. Pharmacological properties of Moringa oleifera II : Screening for antispasmodic, anti-inflammatory and diuretic activity. J Ethnopharmacol 36(3), 233-23. http://dx.doi.org/10.1016/0378-8741\%2892\%2990049-W

CLSI (Clinical and Laboratory Standards Institute). 2004. Performance standards for antimicrobial susceptibility testing; approved standard, 14th ed, document M100-S14. Wayne, PA: Clinical and Laboratory Standards Institute.

Dayrit FM, Angela AD, Villasena IM. 1990. Studies on Moringa oleifera seeds. Part I. The antibiotic compound and its deactivation in aqueous solution. Phillipp J S 119(1), 23-32.

Doughari JH. 2006. Antimicrobial Activity of Tamarindus indica Linn. Trop J Pharm Res 5(2), 597-603.

Doughari JH, El-mahmood AM, Tyoyina I. 2008. Antimicrobial activity of leaf extracts of Senna obtusifolia (L). Afr J Pharm Pharmacol 2(1), 7-13.

D'Souza AL, Rajkumar C, Cooke J. 2002. Probiotics in the prevention of antibiotic-associated diarrhea: meta-analysis. BMJ 324, 1361-1366. http://dx.doi.org/10.1136/bmj.324.7350.1361

Eilert U, Walters B, Nahrstedt A. 1981. The antibiotic principle of seeds of Moringa oleifera and Moringa stenopatala. Planta Med 42(1), 55-61. http://dx.doi.org/10.1055/s-2007-971546

Guevara AP, Vargas C, Sakurai H. 1999. An antitumor promoter from Moringa oleifera Lam. Mutat Res 440, 181-188. http://dx.doi.org/10.1016/S1383-5718\%2899\%2900025-X

Hogenauer C, Hammer HF, Krejs GJ, Reisinger EC. 1998. Mechanisms and management of antibiotic-associated diarrhea. Clin Infect Dis 27, 702-710. http://dx.doi.org/10.1086/514958

Holt JG, Krieg NR, Sneath HA, Staley JT, Williams ST. 1994. Bergey's manual of determinative bacteriology. 9th ed. Williams \& Wilkins Co. 176-189 pp.

Hovius SE, Rietra PJ. 1982. Salmonella colitis clinically presenting as a pseudomembranous colitis. Neth J Surg 34, 8182.

Jabeen R, Shahid M, Jamil A, Ashraf M. 2008. Microscopic evaluation of the antimicrobial activity of seed extracts of Moringa oleifera. Pak J Bot 40, 1349-1358.

Majorie MC. 1999. Plant products as antimicrobial agents. Clin Microbiol Rev 12(4), 564-582.

McFarland LV. (1998) Epidemiology, risk factors and treatments for antibiotic-associated diarrhea. Dig Dis 16, 292-307. http://dx.doi.org/10.1159/000016879

Olukoya DK, Idika N, Odugbemi T. 1993. Antibaterial activity of some medicinal plants from Nigeria. J Ethnopharmacol 39, 69-72. http://dx.doi.org/10.1016/0378-8741\%2893\%2990051-6

Rauha JP, Remes S, Heinonen M, Hopia A, Kahkonen M, Kujala T, Pihlaja K, Vuorela H, Vuorela P. 2000. Antimicrobial effects of Finnish plants extracts containing falvonoids and other phenolic compounds. Int J Food Microbiol 56, 312. http://dx.doi.org/10.1016/S0168-1605\%2800\%2900218-X

Tankanow RM, Ross MB Ertel IJ. 1990. A double-blind, placebo-controlled study of the efficacy of lactinex in the prophylaxis of amoxicillin-induced diarrhea. DICP 24, 382-384.

Wiström J, Norrby SR, Myhre EB, Eriksonn S, Grandström G, Lagergren L. 2001. Frequency of antibiotic-associated diarrhoea in 2462 antibiotic-treated hospitalized patients: a prospective study. J Antimicrob Chemother 47, 43-50. http://dx.doi.org/10.1093/jac/47.1.43. 